\title{
Business cycles, expectations and inflation in Brazil: \\ a New-Keynesian Phillips curve analysis
}

\author{
Elano Ferreira Arruda, Maria Thalita Arruda Oliveira \\ de Olivindo and Ivan Castelar
}

\begin{abstract}
This article analyses Brazil's recent inflation dynamic, considering different expectations environments within the New-Keynesian Phillips curve framework, to observe how the potential for discretionary behaviour by the monetary authority can interfere in economic agents' forward-looking expectations, and how that interference can affect the way inflation responds to its inertial component and to business-cycle fluctuations. To that end, the study estimates the New-Keynesian Phillips curve and its hybrid version, using the heteroscedasticity-and-autocorrelation-consistent (HAC) estimator of the generalized method of moments (GMM). The results suggest that, when economic agents possess lower degrees of foresight, inflation will be more sensitive to business-cycle fluctuations the larger is its inertial component.
\end{abstract}

\section{Keywords}

Economic conditions, business cycles, inflation, economic analysis, econometric models, Brazil

JEL classification

E30, E31, E32

\section{Authors}

Elano Ferreira Arruda is a professor at the Department of Applied Economics and a research fellow on the Postgraduate Programme in Economics of the Federal University of Ceará (UFC), Brazil. Email: elano@ufc.br.

Maria Thalita Arruda Oliveira de Olivindo is a $\mathrm{PhD}$ candidate on the Graduate Programme in Economics of the Federal University of Ceará, Brazil. thalitaoliveira. Email: sobral@gmail.com.

Ivan Castelar is a professor on the Postgraduate Programme in Economics at the Federal University of Ceará, Brazil. Email: lume1250@yahoo.com.br. 


\section{Introduction}

The Phillips curve, initially represented as the trade-off between wage inflation and unemployment, has undergone major changes over the last few decades, owing both to the evolution of macroeconomic theory and to the emergence of new stylized facts on the relationship between business cycles, expectations and inflation.

The most recent change, based on formulations by Taylor (1980) and Calvo (1983), is known as the New-Keynesian Phillips curve (hereinafter NKPC). This is obtained from a microfounded rational-expectations model, which envisages a relationship between short-term inflation and a measure of firms' marginal cost and highlights the importance of forward-looking expectations. Galí and Gertler (1999) also propose a hybrid New-Keynesian Phillips curve, in which the effect of the backward-looking, or inertial, component is also evaluated.

Both NKPC and its hybrid version are currently a focus of debate on the conduct of monetary policy and the relationship between business cycles, ${ }^{1}$ expectations and inflation. This is important because a credible monetary authority can pursue a disinflationary policy at no cost, if inflation is a purely forward-looking process, whereas the cost of such a policy in terms of reduced economic activity could be higher if there is a backward-looking component.

The international literature reveals that studies on the subject are somewhat polarized: some authors show that NKPC is a robust mechanism to explain the inflationary dynamic (Gali and Gertler, 1999; Galí, Gertler and López-Salido, 2001), while others question its empirical relevance (Rudd and Whelan, 2005). In the case of Brazil, several papers present evidence of the importance of the Phillips curve for analysing the behaviour of inflation, although the results are quite sensitive to the estimation methods and proxy variables used in the model (Mendonça, Sachsida and Medrano, 2012; Sachsida, 2013).

The main evidence for the Brazilian economy ${ }^{2}$ reveals the statistical significance of the forwardand backward-looking expectations components for the behaviour of inflation, and the fact that a business-cycle variable measured by the output gap cannot easily capture the effect that changes in economic activity have on price trends (Areosa and Medeiros, 2007; Sachsida, Ribeiro and Dos Santos, 2009; Arruda, Ferreira and Castelar, 2011).

Despite the wide-ranging debate over the appropriateness of NKPC, there has been little discussion on how the recent dynamics of inflation in Brazil respond to its inertial component and to cycles of economic activity, considering different levels of agent foresight, or forward-looking expectations, in NKPC and in its hybrid version. Authors such as Mendonça (2002 and 2004), Sicsú (2002) and Mendonça and Santos (2006) show that the credibility of the monetary authority affects economic agents' predictive capacity and that much of the inertia of inflation stems from the government's reputational loss following its failure to observe the rules previously agreed upon.

Accordingly, this study examines the recent behaviour of Brazilian inflation, considering different expectations environments in the framework of NKPC and its hybrid version. The aim is to answer the following questions: how do the estimated coefficients of NKPC and its hybrid version behave in different forward-looking expectations environments? Would inflation be less sensitive to cyclical output fluctuations and its inertial component if economic agents had perfect foresight? Are the costs of a disinflationary policy -in terms of a reduction in economic activity - higher when economic agents have less foresight? Given that authors such as Simonsen (1970 and 1985), Cabello (2014) and Carvalho (2014) warn that persistent or increased indexation has major inflationary feedback repercussions, did the possible recent increase in the degree of indexation of the Brazilian economy affect the impact of inertial inflation?

\footnotetext{
1 Business cycles as measured by firms' marginal cost.

2 For a good review of the main evidence, see Mendonça, Sachsida and Medrano (2012) and Sachsida (2013).
} 
To answer these questions, the study uses monthly data spanning from January 2002 to December $2012^{3}$ to estimate NKPC and its hybrid version for the Brazilian economy, applying the heteroscedasticity and autocorrelation-consistent (HAC) estimator of the generalized method of moments (GMM). The output gap, unemployment gap and firms' real marginal cost ${ }^{4}$ are used as business-cycle variables; inflation measured by the lagged National Extended Consumer Price Index (IPCA) is used to represent backward-looking expectations; the future projected IPCA proxies forwardlooking expectations under perfect foresight; and, lastly, the average of daily inflation expectations throughout the month following publication of the Central Bank of Brazil's Focus report, serves as a measure of forward-looking expectations in a low-foresight environment.

This study's main contribution is to evaluate how Brazilian inflation responds to oscillations in business cycles and in its inertial component in different forward-looking expectations environments, in addition to testing the unemployment gap as a measure of the business cycle ${ }^{5}$ and using a measure of firms' marginal cost, following Galí and Gertler (1999). It should be noted that the marginal cost measure used in this study has not previously been used in applications for Brazil. ${ }^{6}$

The present study is divided into seven sections, including this introduction. Section II describes the history of Brazilian inflation in recent years, and section III discusses some theoretical aspects of NKPC and its hybrid version, and the relationships between business cycles, expectations and inflation with different degrees of agent foresight. Section IV describes and analyses the data, while section V describes the econometric strategy. Section VI analyses and discusses the results, and the concluding section sets forth final thoughts.

\section{Recent trend of inflation in Brazil}

In an attempt to contain the hyperinflation that devastated the Brazilian economy from the 1980s until the early 1990s, many stabilization plans were implemented without success. Only with the Real Plan, initially based on the tripod of an exchange-rate anchor, a deep fiscal adjustment and rigid monetary base, inflation fell steeply between 1995 and 1998. During that period, the degree of indexation was reduced and, consequently, the inflationary inertia that had been undermining the Brazilian currency eased.

Due to a sharp appreciation of the national currency, Brazil accumulated a large current-account deficit and, thus, became both dependent on international capital inflows and more vulnerable to external shocks (Giambiagi and others, 2011). Following three speculative attacks against the real, during the Mexican crisis (1995), the Asian crisis (1997) and the Russian moratorium (1998), raising interest rates was no longer enough to prevent capital flight, and a steady depletion of reserves forced a devaluation of the real in 1999.

After the exchange-rate anchor had been eliminated, inflation targeting was adopted as a tool to prevent indexation from becoming re-established in the Brazilian economy. Thus, with the defined nominal anchor, the Central Bank set inflation targets for 1999 (8\%), 2000 (6\%) and 2001 (4\%), with a band of tolerance of two percentage points. Contrary to what was expected by those who feared the return of inflation, the currency devaluation had no inflationary effects, and the Extended National

3 This period was chosen because data on firms' marginal cost were available.

4 Firms' real marginal cost is measured as the ratio between the wage bill and gross domestic product (GDP).

5 The unemployment gap as a measure of the business cycle is drawn from Okun's Law, which posits an inverse relation between the output and unemployment cycles.

6 Normally, the indicators used include the output gap, the unemployment gap and installed industrial capacity utilization; but none of these effectively measures firms' marginal cost. 
Consumer Price Index (IPCA) ${ }^{7}$ stayed within the range envisaged in 1999 and 2000. From then on, the new tripod would consist of inflation targeting, a floating exchange rate and fiscal responsibility (primary surpluses). Figure 1 shows the behaviour of inflation in that period.

Figure 1

Brazil: trend of inflation (Extended National Consumer Price Index-IPCA) following the establishment of the targeting system, 2001-2015

(Percentages)

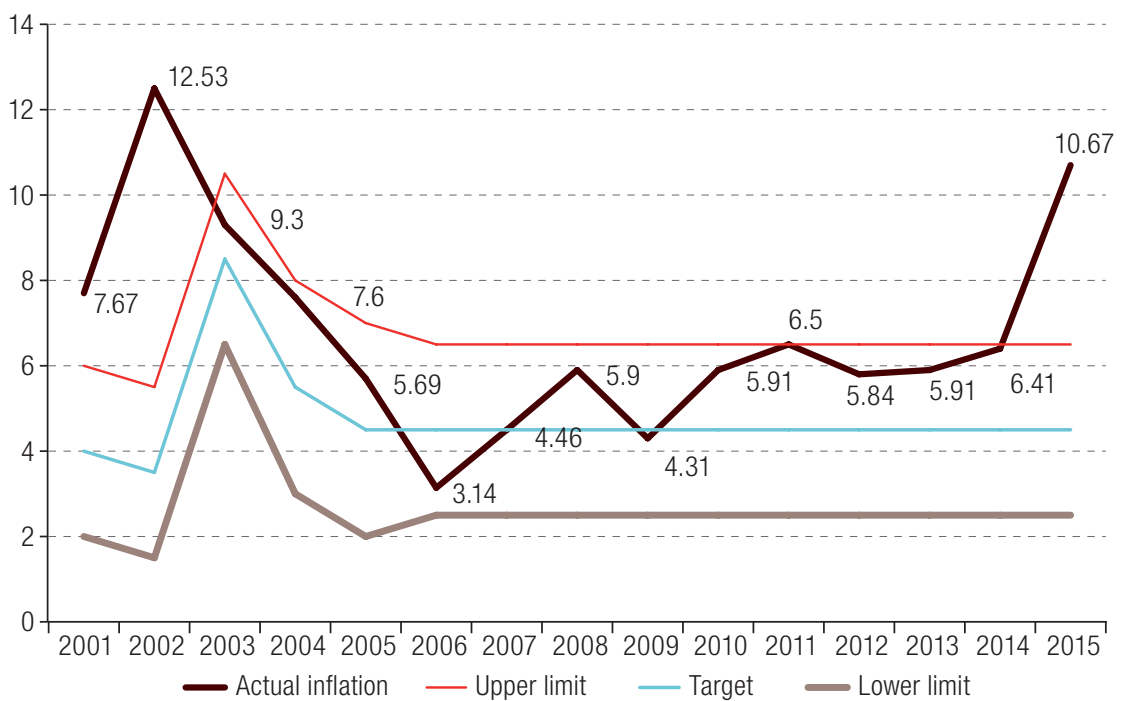

Source: Prepared by the authors.

The situation deteriorated during the electoral campaign of 2002, owing to uncertainty as to the course of economic policy from 2003 onwards. The midpoint of the IPCA target range set for 2002 in 2000 was 3.5\%. In January 2002, the Brazilian economy recorded a cumulative inflation rate of $7.62 \%$ over the preceding 12 months, which gradually rose to $7.93 \%$ by September of that year. When Luiz Inácio Lula da Silva won the elections in October, inflation surged from $8.45 \%$ in that month to $12.53 \%$ by the year-end.

At this point, in January 2003, the central bank set a new inflation target for the year, raising the midpoint of the band from $3.25 \%$ to $8 \%$. When the new government started to behave consistently with the previous monetary policy, indicating that the priorities were control of inflation and fiscal responsibility, the crisis of confidence started to ease, and the inflationary downtrend was resumed, having hit $9.3 \%$ in 2003.

Bresser-Pereira and Gomes da Silva (2008) note that, although domestic savings replaced external savings on a large scale in 2004, the Central Bank kept the interest rate at a high level, and exports boomed. This fuelled an appreciation of the real, which helped bring the IPCA down and attain the inflation target. From then on, inflation trended down until 2006.

The government consolidated the downward path by setting the target for 2005 at 4.5\%; and, between 2004 and 2014, ${ }^{8}$ inflation never strayed outside its target range. This result was mainly due to the appreciation of the real. Nonetheless, the 2007-2008 financial crisis paralyzed external credit sources and caused a devaluation, but inflation still remained below target in 2009.

\footnotetext{
7 The Extended National Consumer Price Index (IPCA) was chosen as a benchmark measure for the targets since it is naturally affected by seasonal factors and temporary shocks.

8 The inflation target has held at 4.5\% per year, but the band was altered to $2.5 \%-6.5 \%$ in 2006 .
} 
The IPCA hit the upper bound of the target range in 2011, owing to rising commodity prices - especially energy and food products - and the rise in the price of international currencies with respect to the real. In the midst of the international crisis of that year, Dilma Rousseff took office as president with a commitment to a new economic framework, characterized by fiscal expansion, abundant credit at subsidized interest rates and a controlled exchange rate. Interest rate cuts began in the second half of 2011 and continued throughout 2012 and early 2013, with the rate falling from $12.42 \%$ to $7.11 \%$.

Moreover, the policy of minimum wage hikes in line with inflation increased the degree of indexation in the economy and thus fuelled inertial inflation. During this period, inflation remained far from the centre of the target range; and, in fact, each year it moved closer to its upper bound. Even with a resumption of increases in the Special Liquidation and Custody System (SELIC) rate, in 2014 the IPCA came in at $6.41 \%$.

Accordingly, the inflation targeting system was abandoned in favour of an expansion of public credit at subsidized interest rates. The focus on developmentalism and the neglect of monetary stability and fiscal equilibrium were clear to see. According to Mesquita (2014), Brazil decided to combat inflation through tariff exemptions and artificial control of the prices on which the public authorities had an influence (administered prices). The State also intervened in exchange-rate policy, announcing a continuous programme of exchange-rate hedging in August 2013, involving daily interventions in the market. On the fiscal-policy front, the primary balance deteriorated steadily to generate a deficit of $\mathrm{R} \$ 32$ billion in 2014. In this context, inflation breached its target ceiling in 2015.

\section{Literature review}

\section{Traditional Phillips curve}

The original version of the Phillips curve depicts an inverse relation between wage inflation and unemployment. In its traditional version, the curve had the following specification:

$$
\pi_{t}=\alpha+\gamma u_{t}+\varepsilon_{t}
$$

where $\pi_{t}$ is wage inflation in period $t, u_{t}$ is the current unemployment rate, and $\alpha$ and $\gamma$ are the parameters, with $\gamma<0$.

According to Phillips (1958), a high unemployment rate would indicate an excess supply of labour, thus putting downward pressure on wages. This meant that economies face a trade-off between inflation and unemployment when formulating and executing economic policies. The IS-LM model was used to analyse the demand side of the economy, while the Phillips curve represented the supply side.

Nonetheless, the idea that a nominal variable (inflation) could affect real variables (the unemployment rate) was heavily criticized in the second half of the 1960s. Authors such as Phelps (1967 and 1969) and Friedman (1968 and 1977) argued that the curve as originally formulated seeks to analyse the growth of nominal wages in relation to unemployment rates, which contradicts the hypothesis that economic agents are rational, since they should be concerned with the behaviour of real variables and not merely with nominal ones. According to these authors, the Phillips curve needed a component to capture inflation expectations.

With low unemployment and thus high inflation, workers would perceive that inflation was higher than expected and would negotiate wages based on this new expectation. Consequently, the unemployment rate would return to its original state, as real wages, having fallen, returned to their former level. This idea initially proposed by Muth (1961) would be called adaptive, or backward-looking, 
expectations, since economic agents correct their expectations on the basis of past forecasting errors. In other words, expected inflation, $\pi_{t}^{e}$, would be modelled as a weighted-average of past inflation rates, with heavier weights attaching to more recent data. The Phillips curve would thus assume the form:

$$
\pi_{t}=\varphi \pi_{t}^{e}+\gamma\left(u_{t}-u_{n}\right)+\varepsilon_{t}
$$

where $\pi_{t}$ is current inflation, and $\pi_{t}^{e}$ is expected inflation in period $t$, formulated as a weighted-average of past inflation rates, $u_{t}$ is the current unemployment rate and $u_{n}$ the natural rate.

This gave agents' expectations a fundamental role in the construction and execution of economic policies. Nonetheless, it was subsequently realized that adaptive expectations would lead economic agents to commit systematic forecasting errors, which is not realistically sustainable.

This finding triggered a revolution in macroeconomic theory between the 1970s and 1980s, driven by the forward-looking rational expectations hypothesis, attributed to Lucas (1972) and Sargent (1971). According to these authors, economic agents predict future inflation by considering all of the information available to them up to the current period, and not just a combination of past data. Thus, expectations become a function of the set of all data available up to $t$, so the Phillips curve also needs a forwardlooking component.

\section{New-Keynesian Phillips Curve}

A new approach to the Phillips curve has been widely discussed in recent decades. Taylor (1980) and Calvo (1983) laid the foundations for the modern analysis of inflation by examining price and wage choices from the perspective of forward-looking families and businesses. In this version, the curve is deduced as a relation between inflation and firms' marginal cost. This formulation, called the New-Keynesian Phillips Curve, is based on two structural equations, namely:

$$
p_{t}=\theta p_{t-1}+(1-\theta) p_{t}^{*}
$$

and

$$
p_{t}^{*}=(1-\beta \theta) \sum_{k=0}^{\infty}(\beta \theta)^{k} E_{t}\left\{c m_{t+k}^{n}\right\}
$$

In equation (3), $p_{t}$ is the aggregate price level and $p_{t}^{*}$ denotes the price level derived from enterprise profit maximization, both in logarithmic form; and $\theta(0<\theta<1)$ is the fraction of firms that do not adjust their prices optimally in $t$. Equation (3) thus introduces a degree of price rigidity, since only a fraction $(I-\theta)$ of the firms can optimally adjust their prices in $t$, while the others retain the prices of the previous period.

Equation (4) can be derived formally by maximizing the present value of firms' expected profits, specifying the optimal price chosen by firms as a function of $\theta$, the real marginal cost, $\mathrm{cm}_{t+k}^{n}$ and a discount factor $\beta$ (Calvo, 1983). In other words, in the absence of friction or adjustment costs, firms would set their prices equal to marginal cost in each period. In practice, however, firms do not change their prices in every period; so the definition of $p_{t}^{*}=c m_{t+k}^{n}$ is not appropriate in this context. Prices have to be formed on the basis of the expected behaviour of marginal cost, so as to maximize the present value of expected profit. Thus, by defining inflation in period $t$ as $\pi_{t}=p_{t}-p_{t-1}$ and combining equations (3) and (4), NKPC can be written as:

$$
\pi_{t}=\lambda c m_{t}+\gamma_{f} E_{t}\left\{\pi_{t+1}\right\}
$$


In other words, current inflation will be a function of firms' real marginal cost in $t$ and expected inflation, which is constructed on a forward-looking basis. Galí and Gertler (1999) show that there is a relation between the marginal cost and the output gap, ${ }^{9}$ which can be expressed as:

$$
c m_{t}=k x_{t}
$$

where $k$ is the elasticity of real marginal cost with respect to the output gap. Substituting this in equation (5) gives:

$$
\pi_{t}=\lambda k x_{t}+\gamma_{f} E_{t}\left\{\pi_{t+1}\right\}
$$

Consequently, period $t$ inflation, $\pi_{t}$, will be a function of the inflation rate expected for the next period, $E_{t}\left\{\pi_{t+1}\right\}$, which is a forward-looking term, and by a business-cycle measure. Thus, NKPC can be estimated using firms' marginal cost and business-cycle variables. ${ }^{10}$

\section{Hybrid New-Keynesian Phillips curve}

Nonetheless, NKPC still contains a major flaw, since it does not include an inertial component, or one based on past inflation. This led to the emergence of the version known as the Hybrid New-Keynesian Phillips Curve (Gali and Gertler, 1999). In this context, $p_{t}^{*}$ takes the following form:

$$
p_{t}^{*}=(1-\omega) p_{t}^{f}+\omega p_{t}^{b}
$$

where $p_{t}^{f}$ is the price set by firms that use forward-looking expectations, and $p_{t}^{b}$ is the price of the set of firms that base their expectations on past experience. ${ }^{11}$ The first group of firms behaves exactly as in the model described by Calvo (1983). So, $p_{t}^{f}$ will be:

$$
p_{t}^{f}=(1-\beta \theta) \sum_{k=0}^{\infty}(\beta \theta)^{k} E_{t}\left\{c m_{t+k}^{n}\right\}
$$

Prices in firms that base their expectations on the past will be expressed as the price level in the last period corrected by inflation. Formally,

$$
p_{t}^{b}=p_{t-1}^{*}+\pi_{t-1}
$$

A combination of equations (3), (8), (9) and (10) produces the hybrid version of NKPC:

$$
\pi_{t}=\lambda c m_{t}+\gamma_{f} E_{t}\left\{\pi_{t+1}\right\}+\gamma_{b} \pi_{t-1}
$$

where $\gamma_{f}$ is the forward-looking term parameter, $\gamma_{f}$ incorporates the past-inflation component, and $\lambda$ incorporates the contribution of firms' marginal cost/business cycles. It should be noted that $\gamma_{b}$ indicates the degree of inflationary persistence; and, if $\gamma_{f}$ is statistically equal to 0 , the traditional Phillips curve formulation is obtained.

\footnotetext{
9 The deviation (in logarithmic form) of output relative to potential, in other words $x_{t} \equiv \hat{Y}_{t}-\hat{Y}_{t}^{n}$.

10 This study uses the output gap, the unemployment gap and firms' real marginal cost.

${ }^{11}$ A fraction $\omega$ of firms form expectations based on the past, while (1- $\left.\omega\right)$ make forward-looking projections.
} 


\section{Description and analysis of the data}

The monthly data used to estimate NKPC and its hybrid version span from January 2002 to December 2012. This sample period was chosen because data are available for the real marginal cost and unemployment gap variables. ${ }^{12}$ Table 1 summarizes the variables used.

Table 1

Description of the variables used

\begin{tabular}{llll}
\hline Indicator & Variable & Representative variable & Source \\
\hline Inflation & Inflation & $\begin{array}{l}\text { Extended National Consumer Price } \\
\text { Index (IPCA) }\end{array}$ & $\begin{array}{l}\text { Brazilian Geographical and Statistical Institute (IBGE)/ } \\
\text { National Consumer Price Indices System (SNIPC) }\end{array}$ \\
\hline \multirow{3}{*}{ Expectations } & Forward-looking expectations & $\begin{array}{l}\text { Projected IPCA inflation } \\
\text { (perfect foresight) }\end{array}$ & IBGE/SNIPC \\
\cline { 2 - 4 } & $\begin{array}{l}\text { FOCUS forecast } \\
\text { (uncertainty hypothesis) }\end{array}$ & FOCUS report of the Central Bank of Brazil \\
\hline Backward -looking & Lagged IPCA inflation & IBGE/SNIPC \\
\hline Business cycles & $\begin{array}{l}\text { Wage bill/gross domestic } \\
\text { product (GDP) }\end{array}$ & $\begin{array}{l}\text { Constructed on the basis of data from IBGE } \\
\text { and the Central Bank of Brazil }\end{array}$ \\
\cline { 2 - 4 } & Real marginal cost & Output gap & $\begin{array}{l}\text { Constructed on the basis of data from the Central } \\
\text { Bank of Brazil and the Hodrick-Prescott filter }\end{array}$ \\
\cline { 2 - 4 } & Unemployment cycle & $\begin{array}{l}\text { Constructed on the basis of data from the employment } \\
\text { and unemployment survey of the State Data } \\
\text { Analysis System Foundation (SEADE) } \\
\text { and the Hodrick-Prescott filter }\end{array}$ \\
\hline
\end{tabular}

Source: Prepared by the authors.

The Extended National Consumer Price Index (IPCA) proxies for inflation. ${ }^{13}$ The information is obtained from the database of the Institute of Applied Economic Research (Ipeadata), sourced in turn from the National Consumer Price Indices System (SNIPC) of the Brazilian Institute of Geography and Statistics (IBGE). This indicator also serves as the government's "official" inflation rate; and it is the index most widely used in studies on Brazil (Schwartzman, 2006; Areosa and Medeiros, 2007; Arruda, Ferreira and Castelar, 2011; Mendonça, Sachsida and Medrano, 2012; Sachsida, 2013).

Two variables were used to consider different forward-looking expectations environments: one of perfect foresight, under rational expectations, in which the projected IPCA is used as a way to model forward-looking expectations (Correa and Minella, 2010; Sachsida, Ribeiro and Santos 2009); and an indicator of weak foresight among economic agents, calculated as the average of daily forecasts for the month following the FOCUS report published by the Central Bank of Brazil (Mendonça, Sachsida and Medrano, 2012; Sachsida, 2013).

The variable that incorporates the inertial, or backward-looking, component of inflation is the lagged IPCA. This measure has traditionally been used in most studies on Brazil (Schwartzman, 2006; Areosa and Medeiros, 2007; Arruda, Ferreira and Castelar, 2011; Mendonça, Sachsida and Medrano, 2012; Sachsida, 2013).

Three business-cycle measures were used in this study: firms' real marginal cost, the output gap and the unemployment gap. The two latter variables were constructed using the Hodrick-Prescott filter. Including the unemployment gap as an alternative is justified by Okun's Law, which invokes an inverse relation between the output and unemployment cycles.

\footnotetext{
12 The data needed to construct these proxy variables for Brazil are only available as from October 2001. In the case of unemployment, the methodology was altered, and the new series is also available as from October 2001.

${ }^{13}$ The IPCA target population encompasses families with monthly incomes, from any source, ranging from 1 to 40 times the minimum wage, and includes residents in the urban areas of metropolitan regions.
} 
The firms' real marginal cost was constructed, following Galí and Gertler (1999), on the basis of the product of the series of real average income of employed persons and the total number of employees $^{14}$ - produced from the IBGE Monthly Employment Survey (PME) and published by the Central Bank of Brazil - and division of the result by gross domestic product (GDP), also provided by the Central Bank of Brazil.

Figure 2, below, shows the cross-correlogram ${ }^{15}$ between some of the variables used in this work, with a view to identifying the direction of the interactions between the business-cycle measures, firms' real marginal cost and inflation. Figure 2.A shows the relation between the output gap and inflation, while Figure 2.B illustrates the relation between the output gap and marginal cost. In figure 2.C, the output gap is replaced by inflation. Lastly, figure 2.D shows the correlation between the unemployment gap and inflation.

Figure 2

Cross correlogram

A. Output gap $(t)$, inflation $(t+k)$

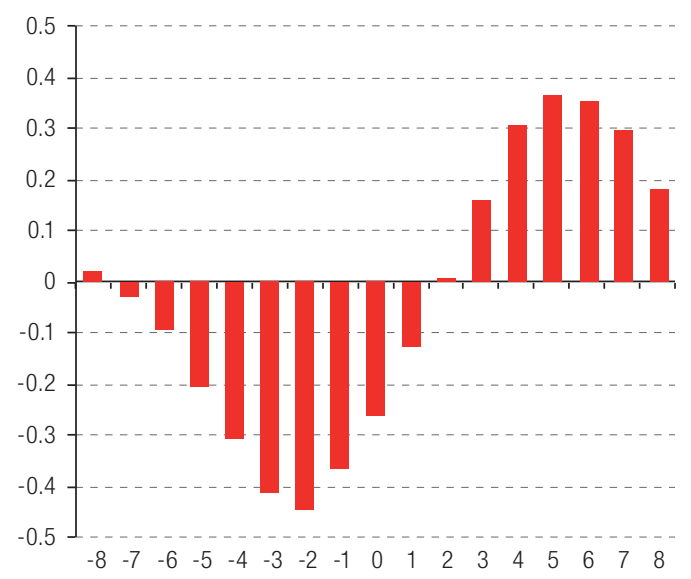

C. Marginal cost $(t)$, inflation $(t+k)$

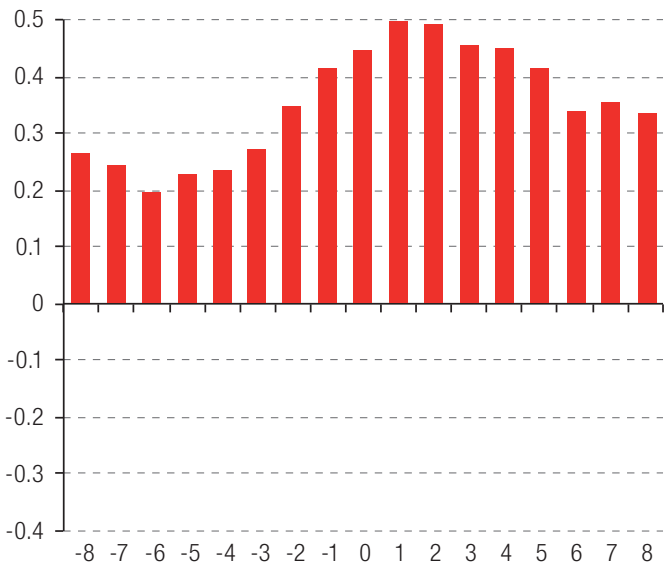

B. Output gap (t), marginal cost $(t+k)$

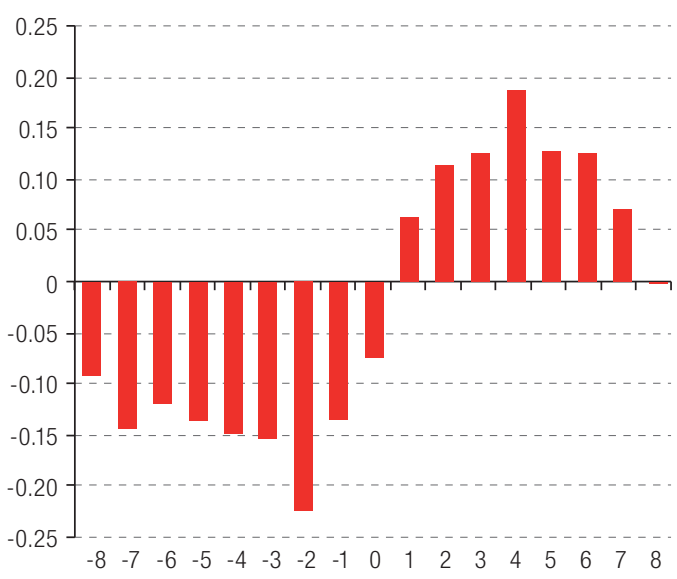

D. Unemployment gap $(t)$, inflation $(t+k)$

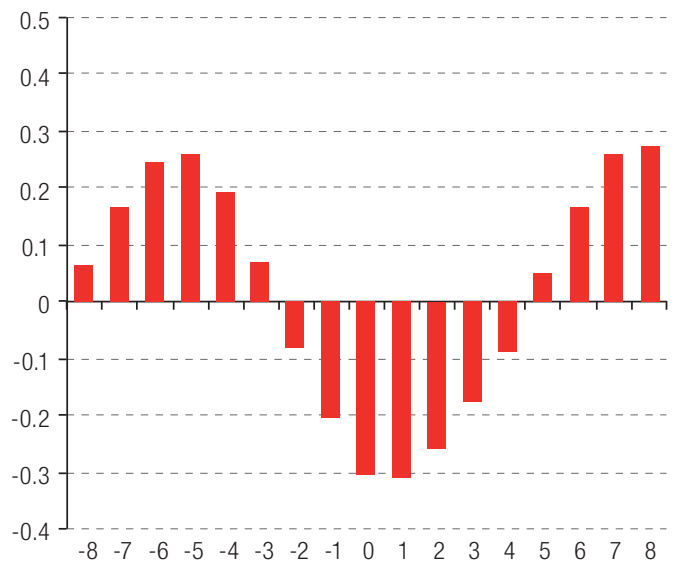

Source: Prepared by the authors.

\footnotetext{
${ }^{14}$ Employees are defined as persons who work for one or more employer, fulfilling working hours and receiving compensation in cash or some other form of payment (housing, food, clothing, among others). Employees are classified according to whether or not they have a formal work contract.

15 The correlogram displays the correlation between the variables. The cross correlations between two series, $x$ and $y$, are given by: $r_{x y}(l)=c_{x y}(l) / \sqrt{c_{x x}(0)} \cdot \sqrt{c_{y y}(0)}$, where $l=0, \pm 1, \pm 2, \ldots$
} 
Figure 2.A indicates that the output gap is positively correlated with future inflation and negatively with past inflation, which justifies the fact that various authors use this lagged measure in empirical models of the Phillips curve (Schwartzman, 2006; Areosa and Medeiros, 2007; Correa and Minella, 2010; Arruda, Ferreira and Castelar, 2011). It should be noted that the negative relation unexpectedly persists until period $t+1$, which corroborates the argument made by Gali and Gertler (1999) that this variable does not easily capture the effects of business cycles on NKPC.

To correct this problem, Galí and Gertler (1999) suggest a measure of firms' real marginal cost. Figure 2.B shows that the contemporary correlation between this variable and the output gap is negative, while figure 2.C shows a positive relation between firms' real marginal cost and inflation, which justifies using that proxy variable. In figure 2.D, the business-cycle measure investigated is the unemployment gap, which is negatively correlated with current inflation. It is important to note that, according to Okun's Law, that variable behaves countercyclically relative to the output gap.

\section{Econometric issues}

The generalized method of moments (GMM), proposed by Hansen (1982), is widely used to estimate rational-expectations models, because, under these conditions, the ordinary-least-squares (OLS) method can produce inconsistent estimates, since the error term is correlated with some of the endogenous regressors. Although the instrumental variables method provides an alternative way to estimate these models, ${ }^{16}$ Baum, Schaffer and Stillman (2003 and 2007) show that GMM is more appropriate in the presence of heterocedasticity.

To choose the best method for estimating the models used here, the Pagan and Hall (1983) heteroscedasticity test ${ }^{17}$ is initially applied in the instrumental variables (IV) estimation, followed by the Cumby and Huizinga (1992) serial autocorrelation test. ${ }^{18}$ Thus, as noted above, if the null hypothesis of homoscedasticity is rejected by the Pagan and Hall test (1983), the GMM estimation corrected for this problem is used; and if the presence of serial autocorrelation is also found, an HAC-GMM estimator is indicated. As heterocedasticity was detected in all of the cases analysed in this study, GMM described below was used.

Consider the following equation, in matrix form, to be estimated:

$$
y=X \beta+u
$$

where $X$ is an $(n \times K)$ matrix of regressors, ${ }^{19}$ including some endogenous ones; in other words, $E\left(X_{i}, u_{i}\right) \neq 0$ for some $X_{i}$. Partitioning the explanatory variables into sets $\left[X_{1} X_{2}\right]$ with $K_{1}$ variables in $X_{1}$ considered endogenous and $K_{2}=\left(K-K_{1}\right)$ exogenous regressors in $X_{2}$ gives:

$$
y=\left[X_{1} X_{2}\right]\left[\beta_{1} \beta_{2}\right]^{\prime}+u
$$

Define $Z$ as an $(n \times L)$ matrix of instrumental variables; in other words, the total number of variables assumed as exogenous, $E\left(Z_{i} u_{i}\right)=0$. The instruments are divided as $\left[Z_{1} Z_{2}\right]$, in which $L_{1}$ instruments, $Z_{1}$, are excluded and the other $L_{2}=\left(L-L_{1}\right)$ instruments $Z_{1} \equiv X_{2}$ are the included instruments/exogenous regressors. Diagram 3 summarizes the variables.

\footnotetext{
${ }^{16}$ Although consistent in the presence of heterocedasticity, the GMM estimator performs poorly in small samples. So, when heterocedasticity is not present, it is preferable to use the instrumental variable (IV) estimator (Baum, Schaffer and Stillman, 2003 and 2007).

${ }^{17}$ A test indicated for the estimation in the presence of endogenous regressors. The null hypothesis consists of homoscedasticity.

18 Test indicated for the IV estimation. The null hypothesis is no autocorrelation.

${ }^{19}$ Where $\mathrm{n}$ is the total number of observations and $\mathrm{K}$ the total number of explanatory variables.
} 


\title{
Diagram 1
}

Regressors and instruments

\author{
Regressors $X=\left[\begin{array}{lll}X_{1} & X_{2}\end{array}\right]=\left[\begin{array}{ll}X_{1} & Z_{2}\end{array}\right]=[$ Endogenous Exogenous $]$
}

Instruments $Z=\left[Z_{1} Z_{2}\right]$ [Exluded Included]

Source: Prepared by the authors.

The equation is fully identified if $L \geq K$; in other words there must be at least as many excluded instruments $L_{1}$ as endogenous regressors $K_{1}$, since $Z_{2}$ is common to both lists. ${ }^{20}$ Hansen (1982) shows that, if the instruments are valid - that is, if they are correlated with the endogenous regressors and not correlated with the error term - the GMM estimators are consistent and asymptotically normal. Therefore, the Hansen (1982) overidentification test ${ }^{21}$ is applied, using the joint null hypothesis that the instruments are valid and the $Z_{1}$ instruments were correctly excluded in the estimation process. If $H_{0}$ is not rejected, the instruments are considered valid and the model is deemed to have been estimated appropriately.

The assumption that the instruments are exogenous can be expressed as $E\left(Z_{i}, u_{i}\right)=0$. Define $g_{i}(\beta)$ as the function $(L \times 1)$ :

$$
g_{i}(\beta)=Z_{i}^{\prime} u_{i}=Z_{i}^{\prime}\left(y_{i}-X_{i} \beta\right)
$$

Thus, the exogeneity of the instruments requires that there to be $L$ moment or orthogonality conditions, such that $E\left(g_{i}(\beta)\right)=0$. The sample counterpart of that moment condition corresponds to:

$$
\bar{g}(\hat{\beta})=\frac{1}{n} \sum_{i=1}^{n} g_{i}(\hat{\beta})=\frac{1}{n} \sum_{i=1}^{n} Z_{i}^{\prime}\left(y_{i}-X_{i} \hat{\beta}\right)=\frac{1}{n} Z^{\prime} \hat{u}
$$

The intuition of the method is to choose an estimator for $\beta$ that minimizes $\bar{g}(\hat{\beta})$ preferably to zero. Therefore, the GMM estimator for $\beta$ is the $\hat{\beta}$ that minimizes the objective function $J(\hat{\beta})$ :

$$
\hat{\beta}_{G M M}=\arg \min J(\hat{\beta})=n \bar{g}(\hat{\beta})^{\prime} W \bar{g}(\hat{\beta})
$$

where $W$ is an $(L x L)$ matrix of weights used to construct a quadratic form for the moment conditions. The efficient GMM estimator uses an optimal weight matrix $W=S^{-1}$ that minimizes the asymptotic variance of the estimator. Deriving the first-order conditions of the previous problem gives:

$$
\hat{\beta}_{G M M}=\left(X^{\prime} Z W Z^{\prime} X\right)^{1}\left(X^{\prime} Z W Z^{\prime} y\right)
$$

Hence, for the GMM estimate of this empirical exercise, the instruments include up to six lags of inflation, the output gap, firms' marginal cost, the unemployment gap and the interest rate, along the lines of Galí and Gertler (1999). The orthogonality conditions of NKPC and its hybrid version are represented by equations (19) and (20), respectively:

$$
\begin{gathered}
E_{t}\left\{\left(\pi_{t}-\lambda m c_{t}-\gamma_{f} \pi_{t+1}\right) z_{t}\right\}=0 \\
E_{t}\left\{\left(\pi_{t}-\lambda m c_{t}-\gamma_{f} \pi_{t+1}-\gamma_{b} \pi_{t-1}\right) z_{t}\right\}=0
\end{gathered}
$$

\footnotetext{
20 Order condition. If $L=K$, the equation is said to be exactly identified; and, if $L>K$, it is overidentified. It should be noted that the order condition is necessary, but not sufficient for identification.

${ }^{21}$ The GMM estimator uses the J-statistic proposed by Hansen (1982), which follows a $X_{L-K}^{2}$ distribution. In the IV estimation, the statistic used is $n R^{2}$, extracted from an auxiliary regression of the IV residuals over the complete set of instruments; it also follows a $X_{L-K}^{2}$ distribution.
} 
In summary, the econometric strategy for estimating the models used in this study involves firstly checking for the presence of heteroscedasticity and serial autocorrelation in the estimation of instrumental variables, using the Pagan and Hall (1983) and Cumby and Huizinga tests (1992), respectively.22 If the $H_{0}$ of homoscedasticity is rejected, GMM is used with a correction for this problem. If serial autocorrelation is also detected, a correction for both problems is applied, in the form of HAC-GMM. Lastly, the Hansen (1982) test of the validity of the instruments is performed; and, if $H_{0}$ is not rejected, the instruments are considered valid and the model is deemed to have been estimated appropriately.

\section{Analysis and discussion of the results}

To study the dynamic of Brazilian inflation in different expectations environments under the NKPC and hybrid NKPC framework, the HAC-GMM method was applied, using monthly data spanning January 2002 to December 2012.

Two forward-looking expectations or foresight environments are thus obtained: perfect foresight -in which the projected IPCA itself is used to form forward-looking expectations - and low foresight - which takes the average of inflation forecasts published in the Central Bank of Brazil's FOCUS report. In addition, each model considers three different business-cycle variables: firms' real marginal cost, the output gap and the unemployment gap. Initially, all the variables were subjected to the augmented Dickey-Fuller and Phillips-Perron unit-root tests, and were stationary at the usual significance levels. The results are summarized in the table 2 .

Table 2

Unit root tests

\begin{tabular}{|c|c|c|}
\hline \multirow{4}{*}{ Series } & Augmented Dickey-Fuller & Phillips-Perron \\
\hline & Statistical test on level & Statistical test \\
\hline & Level & Level \\
\hline & (p-value) & (p-value) \\
\hline \multirow{2}{*}{ Inflation (Extended National Consumer Price Index (IPCA)) } & -4.6799 & -4.3583 \\
\hline & $(0.0013)$ & $(0.0006)$ \\
\hline \multirow{2}{*}{ Marginal cost } & -5.7642 & -5.6681 \\
\hline & $(0.0000)$ & $(0.0000)$ \\
\hline \multirow{2}{*}{ FOCUS forecast } & -4.3523 & -6.3667 \\
\hline & $(0.0038)$ & $(0.0000)$ \\
\hline \multirow{2}{*}{ Unemployment gap } & -4.6979 & -2.9700 \\
\hline & $(0.000)$ & $(0.0407)$ \\
\hline \multirow{2}{*}{ Output gap } & $-3.4498^{*}$ & -3.9297 \\
\hline & $(0.0112)$ & $(0.0025)$ \\
\hline
\end{tabular}

Source: Prepared by the authors.

Note: P-value in parentheses.

Thus, six models are obtained for each forward-looking expectations environment, making a total of 12 models estimated. ${ }^{23}$ Tables 3 and 4 summarize the results of the estimates of NKPC and its hybrid version, respectively.

\footnotetext{
22 If the errors are homoscedastic, Baum, Schaffer and Stillman (2003 and 2007) show that it is better to use the IV estimator, because GMM performs badly in small samples.

23 That is, six models for the New-Keynesian Phillips curve and six for the hybrid version.
} 
Table 3

Estimation of the New Keynesian Phillips curve with HAC-GMM

\begin{tabular}{|c|c|c|c|c|c|c|}
\hline \multirow{2}{*}{ Expectations } & \multirow{2}{*}{ Business cycles } & \multicolumn{2}{|c|}{ Parameters } & \multirow{2}{*}{$\begin{array}{c}\text { J-test } \\
\text { Hansen }\end{array}$} & \multirow{2}{*}{$\begin{array}{c}\text { Heterocedasticity } \\
\text { Pagan and Hall }\end{array}$} & \multirow{2}{*}{$\begin{array}{c}\text { Autocorrelation } \\
\text { Cumby and Huizinga }\end{array}$} \\
\hline & & $\lambda$ & $\gamma_{f}$ & & & \\
\hline \multirow{6}{*}{ Perfect forecast } & \multirow{2}{*}{ Marginal cost } & 0.30 & 0.39 & 4.03 & $X^{2}(5)=29.12$ & $X^{2}(1)=6.92$ \\
\hline & & $(0.01)$ & $(0.00)$ & $(0.25)$ & $(0.00)$ & $(0.00)$ \\
\hline & \multirow{2}{*}{ Unemployment gap } & -0.41 & 0.34 & 7.97 & $X^{2}(14)=21.14$ & $X^{2}(1)=12.10$ \\
\hline & & $(0.04)$ & $(0.01)$ & $(0.78)$ & $(0.04)$ & $(0.00)$ \\
\hline & \multirow{2}{*}{ Output gap a } & -1.97 & 0.59 & 4.43 & $X^{2}(5)=15.54$ & $X^{2}(1)=0.25^{\mathrm{a}}$ \\
\hline & & $(0.00)$ & $(0.01)$ & $(0.22)$ & $(0.00)$ & $(0.62)$ \\
\hline \multirow{6}{*}{ Focus forecast } & \multirow{2}{*}{ Marginal cost } & 0.38 & 1.09 & 3.23 & $X^{2}(5)=20.19$ & $X^{2}(1)=43.13$ \\
\hline & & $(0.00)$ & $(0.00)$ & $(0.35)$ & $(0.00)$ & $(0.00)$ \\
\hline & \multirow{2}{*}{ Unemployment gap } & -0.91 & 1.23 & 7.82 & $X^{2}(15)=27.13$ & $X^{2}(1)=43.13$ \\
\hline & & $(0.00)$ & $(0.00)$ & $(0.85)$ & $(0.02)$ & $(0.00)$ \\
\hline & \multirow{2}{*}{ Output gap } & -0.24 & 1.27 & 5.87 & $X^{2}(15)=23.55$ & $X^{2}(15)=46.94$ \\
\hline & & $(0.52)$ & $(0.00)$ & $(0.95)$ & $(0.05)$ & $(0.00)$ \\
\hline
\end{tabular}

Source: Prepared by the authors on the basis of the equation $\pi_{t}=\lambda x_{t}+\gamma_{f} E_{t}\left\{\pi_{t+1}\right\}$.

Note: P-value in parentheses. The autocorrelation and heteroscedasticity tests were applied in the IV estimation.

a Model corrected for heteroscedasticity only.

Table 4

Estimation of the hybrid New-Keynesian Phillips curve with HAC-GMM

\begin{tabular}{|c|c|c|c|c|c|c|c|}
\hline \multirow{2}{*}{ Expectations } & \multirow{2}{*}{ Business cycles } & \multicolumn{3}{|c|}{ Parameters } & \multirow{2}{*}{$\begin{array}{c}\text { J-test } \\
\text { Hansen }\end{array}$} & \multirow{2}{*}{$\begin{array}{l}\text { Heterocedasticity } \\
\text { Pagan and Hall }\end{array}$} & \multirow{2}{*}{$\begin{array}{c}\text { Autocorrelation } \\
\text { Cumby and Huizinga }\end{array}$} \\
\hline & & $\lambda$ & $\gamma_{f}$ & $\gamma_{b}$ & & & \\
\hline \multirow{6}{*}{ Perfect forecast } & \multirow{2}{*}{ Marginal cost } & 0.17 & 0.30 & 0.53 & 5.37 & $X^{2}(10)=22.35$ & $X^{2}(1)=15.69$ \\
\hline & & $(0.01)$ & $(0.00)$ & $(0.00)$ & $(0.61)$ & $(0.01)$ & $(0.00)$ \\
\hline & \multirow{2}{*}{ Unemployment gap } & -0.26 & 0.39 & 0.52 & 8.77 & $X^{2}(16)=25.98$ & $X^{2}(1)=32.75$ \\
\hline & & $(0.01)$ & $(0.00)$ & $(0.00)$ & $(0.79)$ & $(0.05)$ & $(0.00)$ \\
\hline & \multirow{2}{*}{ Output gapa } & -0.30 & 0.30 & 0.55 & 6.35 & $X^{2}(16)=25.50$ & $X^{2}(1)=33.15$ \\
\hline & & $(0.23)$ & $(0.03)$ & $(0.00)$ & $(0.49)$ & $(0.06)$ & $(0.00)$ \\
\hline \multirow{6}{*}{ FOCUS forecast } & \multirow{2}{*}{ Marginal cost } & 0.31 & 0.22 & 0.61 & 9.07 & $X^{2}(17)=38.83$ & $X^{2}(1)=0.99^{*}$ \\
\hline & & $(0.00)$ & $(0.03)$ & $(0.00)$ & $(0.82)$ & $(0.00)$ & $(0.32)$ \\
\hline & \multirow{2}{*}{ Unemployment gap } & -0.75 & 0.24 & 0.63 & 6.94 & $X^{2}(14)=28.69$ & $X^{2}(1)=16.22$ \\
\hline & & $(0.00)$ & $(0.00)$ & $(0.00)$ & $(0.80)$ & $(0.01)$ & $(0.00)$ \\
\hline & \multirow{2}{*}{ Output gap } & 0.16 & 0.22 & 0.67 & 7.34 & $X^{2}(16)=35.23$ & $X^{2}(1)=11.24$ \\
\hline & & $(0.48)$ & $(0.03)$ & $(0.00)$ & $(0.77)$ & $(0.01)$ & $(0.00)$ \\
\hline
\end{tabular}

Source: Prepared by the authors on the basis of equation $\pi_{t}=\lambda x_{t}+\gamma_{f} E_{t}\left\{\pi_{t+1}\right\}+\gamma_{b} \pi_{t-1}$.

Note: P-values in parentheses. The autocorrelation and heteroscedasticity tests were applied in the IV estimation.

a Model corrected for heteroscedasticity only.

Initially, the Pagan and Hall (1983) test indicated the presence of heterocedasticity in all of the models in the IV estimation, so GMM was chosen. Moreover, the Cumby and Huizinga (1992) test verified the absence of autocorrelation only in NKPC models with perfect foresight which used the output gap as a business-cycle variable, and in hybrid NKPC models under uncertainty (FOCUS forecast) which used firms' real marginal cost as the business-cycle variable. In those cases, GMM was corrected for heteroscedasticity only. In addition, the Hansen (1982) test does not reject the $H_{0}$ of validity of the instruments in any of the models estimated; so, under these conditions, the models have been estimated appropriately.

The estimated coefficient of the output gap variable is either statistically equal to 0 or else displays the opposite sign to that predicted by theory. This result confirms the evidence reported in the literature, both national (Mazali and Divino, 2010; Mendonça, Sachsida and Medrano, 2012; Sachsida, 2013) and international (Galí and Gertler, 1999; Galí, Gertler and López-Salido, 2001), which corroborates the difficulty of using this indicator as a business-cycle measure to explain the dynamics of inflation. 
Nonetheless, for the period analysed, NKPC and its hybrid version served as robust mechanisms to explain the Brazilian inflationary dynamic, since the business-cycle variables - measured by firms' real marginal cost and the unemployment gap - were statistically significant and displayed the signs predicted by theory. The evidence also confirms the statistical significance of the backward- and forward-looking expectations components, and that the impact of the former is relatively greater. This suggests that the recent dynamics of Brazilian inflation still retain a significant inertial component. In other words, according to Simonsen (1970 and 1985), Cabello (2014) and Carvalho (2014), the memory of hyperinflations and the recent increase in indexation in the Brazilian economy may explain this greater influence of inflationary inertia.

The results also seem to indicate that inflation is more vulnerable to the cyclical fluctuations in economic activity in a low-foresight environment, because the absolute impact of these variables is much greater when the FOCUS forecast is used as a forward-looking expectations variable. Thus, as noted by Sicsú (2002) and Mendonça (2002 and 2004), the lower the ability of economic agents to forecast the future, the higher the cost of a disinflation policy in terms of cyclical fluctuations in economic activity.

Lastly, the evidence also suggests that, in a low-foresight environment, inflation is more susceptible to the inertial, or backward-looking component, since the impact of this variable on inflationary dynamics is greater in all of the models considered.

\section{VII.Final thoughts}

This study has analysed the dynamics of Brazilian inflation under different expectations hypotheses under the NKPC and hybrid NKPC frameworks, using monthly data spanning January 2002 and December 2012, and HAC-GMM.

In general, the results confirmed the inadequacy of the output gap, but the robustness of the unemployment gap and firms' marginal cost, as mechanisms for capturing the transmission of business cycles to inflation in Brazil during the period analysed. In other words, the firms' real marginal cost measure, as used in this study, provides an alternative for future applications in Brazil. The results also suggest the relevance of backward- and forward-looking expectations, and that the impact of the former is relatively greater, which means that the Brazilian inflationary dynamic still retains a significant inertial component. It can thus be said that NKPC and its hybrid version are suitable frameworks for investigating the recent Brazilian inflation dynamic.

The evidence also suggests that inflation is more sensitive to business-cycle fluctuations, the lower the degree of foresight possessed by economic agents. In fact, as Sicsú (2002) and Mendonça (2002 and 2004) argue, the less ability economic agents have to predict the path of inflation, the higher the economic-activity cost of a disinflation policy.

Lastly, the inertial component of inflation seems to have a greater effect in a lower foresight environment. In other words, the recent increase in the degree of indexation of the Brazilian economy, related to its memory of hyperinflation, seems to influence the inflationary inertia mechanism; and lower foresight imposes a high cost in terms of perpetuating past inflation in the present.

In short, the results obtained show that, the greater the foresight among economic agents, the less costly disinflation policies will be, both in terms of cyclical fluctuations in economic activity and in the inertial transmission of inflation. 


\section{Bibliography}

Areosa, W. D. and M. Medeiros (2007), "Inflation dynamics in Brazil: the case of a small open economy", Brazilian Review of Econometrics, vol. 27, No. 1, Rio de Janeiro.

Arruda, E. F., R. T. Ferreira and I. Castelar (2011), "Modelos lineares e não lineares da curva de Phillips para a previsão da taxa de inflação no Brasil”, Revista Brasileira de Economia, vol. 65, No. 3, Rio de Janeiro, Getulio Vargas Foundation.

Baum, C. F., M. E. Schaffer and S. Stillman (2007), "Enhanced routines for instrumental variables/generalized method of moments estimation and testing", The Stata Journal, vol. 7, No. 4. (2003), "Instrumental variables and GMM: estimation and testing", The Stata Journal, vol. 3, No. 1.

Bresser-Pereira, L. C. and C. Gomes da Silva (2008), "Inflation targeting in Brazil: a Keynesian approach", Keynes and Macroeconomics after 70 Years: Critical Assessments of the General Theory, L. R. Wray and M. Forstater (eds.), Cheltenham, Edward Elgar.

Cabello, A. F. (2014), "Mário Henrique Simonsen e a construção do conceito de inflação inercial", Brazilian Journal of Political Economy, vol. 34, No. 2, São Paulo, Center of Political Economy.

Calvo, G. A. (1983), "Staggered prices in a utility-maximizing framework", Journal of Monetary Economics, vol. 12, No. 3, Amsterdam, Elsevier.

Carvalho, A. R. (2014), "A persistência da indexação no Brasil pós-real", Brazilian Journal of Political Economy, vol. 34, No. 2, São Paulo, Center of Political Economy.

Correa, A. S. and A. Minella (2010), "Nonlinear mechanisms of the exchange rate pass-through: a Phillips curve model with threshold for Brazil", Revista Brasileira de Economia, vol. 64, No. 3, Rio de Janeiro, Getulio Vargas Foundation.

Cumby, R. E. and J. Huizinga (1992), "Testing the autocorrelation structure of disturbances in ordinary least squares and instrumental variables regressions", Econometrica, vol. 60, No. 1, New York, The Econometric Society.

Friedman, M. (1977), "Nobel lecture: inflation and unemployment", Journal of Political Economy, vol. 85, No. 3, Chicago, The University of Chicago Press.

(1968), "The role of monetary policy", American Economic Review, vol. 58, No. 1, Nashville, Tennessee, American Economic Association.

Galí, J. and M. Gertler (1999), "Inflation dynamics: a structural econometric analysis", Journal of Monetary Economics, vol. 44, No. 2, Amsterdam, Elsevier.

Galí, J., M. Gertler and J. D. López-Salido (2001), "European inflation dynamics”, European Economic Review, vol. 45, No. 7, Amsterdam, Elsevier.

Giambiagi, F. and others (2011), Economia brasileira contemporânea, Rio de Janeiro, Elsevier Editora Ltda.

Hansen, L. P. (1982), "Large sample properties of generalized method of moments estimators", Econometrica, vol. 50, No. 4, New York, The Econometric Society.

Lucas, R. E. (1972), "Expectations and the neutrality of money", Journal of Economic Theory, vol. 4, No. 2, Amsterdam, Elsevier.

Mazali, A. A. and J. A. Divino (2010), "Real wage rigidity and the New Phillips curve: the Brazilian case", Revista Brasileira de Economia, vol. 64, No. 3, Rio de Janeiro, Getulio Vargas Foundation.

Mendonça, H. F. (2004), "Mensurando a credibilidade do regime de metas inflacionárias no Brasil", Brazilian Journal of Political Economy, vol. 24, No. 3, São Paulo, Center of Political Economy. (2002), "A teoria da credibilidade da política monetária", Brazilian Journal of Political Economy, vol. 22, No. 3, São Paulo, Center of Political Economy.

Mendonça, M. J. C., A. Sachsida and L. Medrano (2012), "Inflação versus desemprego: novas evidências para o Brasil", Economia Aplicada, vol. 16, No. 3, São Paulo, University of São Paulo.

Mendonça, H. F. and M. A. L. dos Santos (2006), "Credibilidade da política monetária e a previsão do tradeoff entre inflação e desemprego: uma aplicação para o Brasil”, Economia, vol. 7, No. 2, Brasilia, National Association of Centers for Post-graduation in Economics.

Mesquita, M. (2014), "A política econômica do governo Dilma: a volta do experimentalismo", Sob a luz do sol: uma agenda para o Brasil, São Paulo, Center for Public Policy Debate.

Muth, J. F. (1961), "Rational expectations and the theory of price movements", Econometrica, vol. 29, No. 3, New York, The Econometric Society.

Pagan, A. R. and D. Hall (1983), "Diagnostic tests as residual analysis", Econometric Reviews, vol. 2, No. 2, Taylor \& Francis. 
Phelps, E. S. (1969), "The new microeconomics in inflation and employment theory", American Economic Review, vol. 59, No. 2, Nashville, Tennessee, American Economic Association.

_ (1967), "Phillips curves, expectations of inflation and optimal unemployment over time", Economica, vol. 34, No. 135, Wiley.

Phillips, A. W. (1958), "The relationship between unemployment and the rate of change of money wage rates in the United Kingdom, 1861-1957", Economica, vol. 25, No. 100, Wiley.

Rudd, J. and K. Whelan (2005), "New tests of the new-Keynesian Phillips curve", Journal of Monetary Economics, vol. 52, No. 6, Amsterdam, Elsevier.

Sachsida, A. (2013), "Inflação, desemprego e choques cambiais: uma revisão da literatura sobre a curva de Phillips no Brasil”, Revista Brasileira de Economia, vol. 67, No. 4, Rio de Janeiro, Getulio Vargas Foundation.

Sachsida, A., M. Ribeiro and C. H. dos Santos (2009), "A curva de Phillips e a experiência brasileira", Texto para Discussão, No. 1459, Brasilia, Institute of Applied Economic Research (IPEA).

Sargent, T. J. (1971), "A note on the 'accelerationist' controversy", Journal of Money, Credit and Banking, vol. 3, No. 3, Ohio, Ohio State University Press.

Schwartzman, F. (2006), "Estimativa de curva de Phillips para o Brasil com preços desagregados", Economia Aplicada, vol. 10, No. 1, São Paulo, University of São Paulo.

Sicsú, J. (2002), "Expectativas inflacionárias no regime de metas de inflação: uma análise preliminar do caso brasileiro", Economia Aplicada, vol. 6, No. 4, São Paulo, University of São Paulo.

Simonsen, M. H. (1970), Inflação: gradualismo x tratamento de choque, Rio de Janeiro, APEC Editora.

_ (1985), "Contratos salariais justapostos e política anti-inflacionária", Revista de Econometria, vol. 5, No. 2, Rio de Janeiro.

Taylor, J. B. (1980), "Aggregate dynamics and staggered contracts", Journal of Political Economy, vol. 88, No. 1, Chicago, The University of Chicago Press. 